\title{
Research on Service Pattern of Storing Local Government Information into University Libraries in Big Data Age
}

\author{
Linlin Zhang \\ Heilongjiang Bayi Agricultural University Library, Heilongjiang Bayi Agricultural University, Daqing, China \\ Email: liblin@126.com
}

Received 23 November 2015; accepted 14 February 2016; published 17 February 2016

Copyright (C) 2016 by author and Scientific Research Publishing Inc. This work is licensed under the Creative Commons Attribution International License (CC BY). http://creativecommons.org/licenses/by/4.0/ cc) (i) Open Access

\begin{abstract}
Under the big data environment, this paper proposes the system building pattern and effective service strategy of storing government information into university libraries. The local government information can be better co-built and shared by establishing the guarantee institution for government information storage at university library and effectively integrating the government information resources, and providing diversified services of local government information to the public.
\end{abstract}

\section{Keywords}

Government Information, University Library, Storage Institution, Diversified Service, Co-Building and Sharing

\section{Introduction}

Although the governments are the largest owner of the information resources in China, these information resources are not effectively exchanged and communicated, most information resources can not be effectively developed and utilized, and information resources are not shared to the society due to no uniform government information storage system. To share the government information resources, we should depend on electronic E-government platform and strengthen resource construction cooperation with the reference collectors in order to ensure smooth sharing of information resources.

"Publication regulation" regulates that the government information is publicized via the public library in China. As a key reference collector, compared to the public library, the university library is suitable for storing the government information due to its strengths in talents, devices and resources. In recent years, partial university 
libraries have started to serve for local social economy construction and mass and maximize its role as the information and culture communication organization based on their capabilities. e.g. Guangzhou University library cooperates with the governmental authorities to build the Guangzhou governmental consulting hall, which provides governmental information, government archive inquiry, and office guidance [1]. Nankai University and China Mining University integrate the governmental resources and provide reference information services to related industries [2]. These services launch the pattern of publicizing the governmental information resources via the domestic university libraries to some extent. Compared to China, the government information is stored into the university libraries, which becomes the key channel and platform for the public to acquire and utilize the governmental information resource. e.g. the Las Vegas branch library of University of Nevada builds "government information and publication portal website”, which updates and arranges the governmental information in continuous change in order to ensure instant and authoritative government information. The reference center website of Michigan University sets Web feed, which can push government information to the public desktop via RSS technology [3]. University of North Texas library cooperates with the America Publication Bureau to develop "government webpage archiving items", which provides permanent public retrieval of withdrawn government websites and electronic publication [4]. Under the big data environment, the university libraries should participate in the local government information service to explore the self-development space, change to the smooth channel for communicating the local government information, and provide more services for co-building and sharing of the local government information resources.

\section{Target Principles and Content of Government Information of Deposit Libraries in Colleges and Universities}

\subsection{Goals of Public Service}

The deposit library program of colleges and universities has two main goals for the public service. The public can access to government information resources and it can provide assistance when the public uses government information resources.

\subsection{Principles of Public Service}

The public service of deposit libraries in colleges and universities needs to insist on two basic principles, including the principle of free access and the principle of comparable treatment. Relevant laws and regulations shall be formulated. The specified deposit libraries in colleges and universities must provide the public with free access to all the government information products. The service of access to government information resources of deposit libraries in colleges and universities shall be equal or more than other library collection services. The reference consulting services of government information resources provided by deposit libraries in colleges and universities to the public must be comparable to the basic library reference consulting service provided by the libraries to the main users.

\subsection{Content of Public Service}

The key objective of deposit libraries in colleges and universities is to provide the public with free online access of government information resources with public interest and education value. And there is no need to consider the format and media of the information resources. It is ensured that in spite of technological changes in the past or in the future, the users can get assess for the long term. Only the government information purely issued for administrative purpose, and that involving national security secrets, personal privacy and publication in cooperation must be sold, so that the self-sustaining government information can be excluded.

\section{Strengths of Storing Government Information into University Libraries}

With development of information technology, the university libraries will transform to the multi-function and unidirectional reference information center, and extend and expand service functionalities as much as possible to meet demands of more masses. As a traditional technology reference information center, compared to other reference organizations, the university libraries have distinct strengths in storage of the government information. 


\subsection{Strengths in Hardware Facilities}

The university libraries have distinct strengths in network facilities, digital technology and reference carrier. In recent years, the university libraries evolve much in networking, automation and digitalization. Based on the investigation data, the wireless network coverage rate of the university libraries reaches $49.2 \%$. The mean storage capacity of the digital resources is about 44.3 TB. 50\% university libraries have $501-1000 \mathrm{M}$ backbone network. The Huiwen, Jinpan and ILAS reference systems are extensively used. Many university libraries are united via Internet. They provide better information service experiences to the public via high capacity, high speed and advanced information transmission, so they provide enough hardware conditions for the university libraries to storage the local government information.

\subsection{Strength in Information Technology and Talent Supply}

Most university libraries have their information management academies, so they have distinct strengths in advanced information technology intervention, and rich software development and information technology application experiences. All university libraries have their perfect reference information organization and classification system, modern information processing technology and information retrieval technology. Librarians can analyze information requirements of the public, proactively provide required information to users and satisfy different demands of users via selection, analysis, arrangement, integration and Push technology. These lay the technology foundation for quick information transmission. Some university libraries establish the resource sharing and cooperation with other university libraries via the network in order to provide deep reference and consulting services to the public.

The university libraries have hybrid librarians in book intelligence specialty, who have higher degrees, professional knowledge and practical experiences, and can arrange and retrieve the information resources. These librarians not only are proficient computer knowledge, but also effectively transmit and manage collected information, provide information retrieval and deep information processing according to different retrieval requirements and retrieval contents of the public, and satisfy information consulting services of the public in different forms and levels.

\section{Establish Guarantee Institution for Storing Government Information into the University Libraries}

\subsection{Set government Management Coordination Organization for Effective Operation}

Although "public regulation" is issued to make the libraries join in the governmental information publication system. It is difficult to guarantee its status and role on the current phase [5]. To effectively storage government information into libraries, corresponding laws and regulations should be prepared to ensure that the university libraries can restrict governments in information storing. To establish effective cooperation with the governments for a long period, the independent government management coordination organization should be set in the governmental department, so it can regularly ask the electronic and paper government publications and guide storage service of the university libraries in order to effectively storage the government information into the university libraries.

\subsection{Establish Take-Over Institution for Storing the Government Information into the University Libraries}

The government information should not be only temporarily stored in the university libraries. Although how to storage the government information into the university libraries is in exploration, the university libraries and government organizations should focus on this work and normalize this work, so the laws in organization construction, implementation mode and functionality should be issued, so more masses can know how to acquire the required government information by using the university libraries. The university libraries can better embody the property of the organization and ensure references with their professional strengths.

\subsection{Uniformly Prepare Government Information Storing Standard}

To better share the govern information resources, the uniform government information description standard 
should be prepared at the beginning. The metadata from different departments and different government information should be scientifically organized, uniformly indexed, effectively reflected by using the reference classification method, so the unused subject databases can be obtained. The public can quickly inquire the required government information by using the corresponding search engine.

\section{Effective Integration of University Libraries to the Governmental Information Resources}

To storage the government information into the university libraries, the government information center as the leader, universities as dependent party, and government information management coordination organization will compose a digital network library for co-building and sharing of the information resources. This digital network library is the local uniform digital reference information center, which can provide omnidirectional and diversified reference information service to ranks in the society. Three parties should have specific responsibilities and tasks. The local government information center should completely coordinate and lead construction and operation of the whole project. The university libraries should be responsible for development, design and maintenance of the portal website. The government information management coordination organization should be responsible for public advertisement and resource construction. Three parties should select and maintain the resources together and provide effective recommendations and comments to digital network information service.

\subsection{Collection Mode and Range of Stored Information in Libraries}

The university libraries can be assigned with the storing persons, who will contact the government organizations, and collect, catalog and serve the government information resources. The storing persons can select category information suitable for collection via the collection tools, and form corresponding subject list as the collection list of storing library. The library collection subjects are added or deleted after careful consideration and demonstration. Once the subject items are identified, the related leaders of the government information center should automatically distribute related government information according to the storing subjects of the libraries by using the automated storing distribution system.

To better satisfy diversified information requirements of the social public, the university storing libraries should set collection range of government information in advance. This range can be regularly changed according to the change of the public information demand to ensure that the collected government information resources can satisfy public demands. University libraries should select the subject range, age and format of the government information as wide as possible, so the libraries can provide effective reference consulting and information retrieval service and meet demands of general public. The libraries should set the required items and optional items. The required items should include the very important governmental information and can be classified by the subject list. The optional items include the characteristic government resources, or items strongly recommended by the public. The university libraries can not collect all government information resources. To improve utilization rate of resources and save the librarian time, the university library should cooperate with the government information center in collection, so the storing libraries can provide comprehensive information resource service to the public in the area.

\subsection{Information Distribution Management and Storage of Storing Libraries}

The university libraries will submit the list of the collected information to the government coordination organization, which will ask the published government information to the government according to the list contents. The government organization can pack the tangible publications and post them to the university libraries, and provide the online link URL of the electronic publications for retrieval, which can support precise retrieval, fuzzy retrieval and resource maintainer retrieval entrance. The university library should establish the correct government information receiving and saving institution to publicize the received electronic government information quickly, and should establish the long-period mechanism for receiving information together with the government. The minimal standard for saving and maintenance should not be inferior to it of other reference type. The references can be saved selectively and permanently. The selective references can be stored for at least 5 years. The discarded government information should be agreed by the government department and be returned. The permanent stored documents should be stored by priority. 


\section{University Libraries Provide Governmental Information to Public via Diversified Service Mode}

Now some university libraries have implemented the government information services in China, but many problems occur. The libraries can not closely associate the governments, publicize them in place, and provide narrow acquisition channels to the public, and low-level service. To better serve the local government, the local government should strengthen advertisement, deepen service content, and ask for government support for change.

\subsection{Strengthen Internal Training and Learning}

The storing university libraries should focus on storing of the government information. The library leaders and general workers should be familiar with storing flow of the government information resources and acquisition mode of resources, so training and learning should be performed inside the libraries prior to external advertisement to ensure that librarians accurately provide timely service consulting service to the public. Training involves use method of automated software, knowing of government laws and regulations, application procedure of general government business, and retrieval method of government websites and database. In addition, training should include access policies, opening time, service standard, device use and collection development of the storing libraries. The university libraries should make the librarians know knowledge on government information via crossing learning and investigation, exchange with the administrative departments and archive library, establish cooperation relation, and provide timely and effective government information service to the public.

\subsection{Carry out External Advertisement and Training}

To make the public know that the university libraries provide the local government information, the university libraries should advertise the collection service contents the public and make the public know it. e.g. the libraries can advertise via the following means and modes: 1) Post marks of the storing library. The university libraries should post the marks at the remarkable positions, so the public can know that the libraries can provide the governmental information service; 2) Place the advertisement manual. Place the brochure at the remarkable position of the library entrance, so the public can know type and search mode of the stored government information. 3) Establish the website and webpage of stored government information. Embed the government information retrieval portal at the remarkable position on the retrieval pages of the library electronic platform and provide important government information link to the public.

\subsection{Carry out Reference Consulting Services via Multiple Modes}

To achieve better government information service effect, the libraries can set the public reference consulting center to solve consulting problems on government information in a face-to-face manner, e.g. library collection layout, storage location of government information, use guidance of collected references, consulted issues, and resource commendation, and explain how to acquire the required reference from other libraries via the inter-library borrowing The librarians should further expand the reference consulting service means via post, telephone, email, fax and online service. They can provide different replies according to the type of the public consulting issues to ensure that the public can acquire the useful information quickly.

\section{Conclusion}

In a word, under the big data environment, by combing self-features and strengths, the university libraries should deeply carry out and fulfill the spirit of the central party on public information construction, establish and perfect the guarantee institution for storing the government information to libraries, collect, organize and integrate massive government information in time, make the public effectively acquire the required information in time via one-stop convenient manner, fully release the information energy of the big data, and make the public know the information to most extent.

\section{Funding}

Daqing Philosophy and Social Science Plan research project "Research on system building and service strategy 
of storing local government information into Daqing university library” (project number: DSGB2015079).

Heilongjiang Philosophy and Social Science Plan research project "Information service system building of university libraries in big data age” (project number: 14E045).

\section{References}

[1] Chen, J.L. and Wang, J.D. (2009) Analysis on Service Development Pattern and Hot Issue Fields of Local Government Information in China. Library and Intelligence Service, 24, 55-58.

[2] Wu, N.Y. (2010) Research on Strategy for University Libraries to Serve the Local Governments. Hebei Science and Technology Map, 3, 32-34.

[3] Cheng, M.Q. and Peng, G.L. (2010) Current Conditions and Pattern of Government Information Resource Collection in America Storing Libraries. Library Forum, 2, 29-31.

[4] Li, Y.W. and Yu, C.P. (2011) Storing Library Pattern and Application Research. Library Work and Research, 12, 21-23.

[5] Yan, L.P., Shen, C. and Zhang, L. (2015) Thinking on Perfecting Local Government Information Publication in Big Data Age. Legality Vision, 1, 38. 